\title{
IMPLEMENTASI KEBIJAKAN ABSENSI SIDIK JARI (FINGER PRINT) DALAM MENINGKATKAN KINERJA PEGAWAI NEGERI SIPIL DI SEKRETARIAT DAERAH KABUPATEN BANGKA TENGAH PROVINSI KEPULAUAN BANGKA BELITUNG
}

\author{
Oleh \\ Zia Komaria ${ }^{1}$, \\ Bahrullah Akbar ${ }^{2}$, Rizari ${ }^{3}$ \\ 1) Pemerintah Kabupaten Bangka Tengah \\ Program Magister Terapan Studi Pemerintahan Daerah Institut Pemerintahan Dalam Negeri \\ ziakomaria4@gmail.com \\ ${ }^{2,3)}$ Institut Pemerintahan Dalam Negeri
}

\begin{abstract}
$P^{\prime}$ olicy implementation for fingerprints within the regional secretariat Kabupaten Bangka central in general are in accordance with the regulations government policy government number 53 year 2010 on discipline of civil servant, but whether in the electronic attendance this policy improve performance civil within the regional secretariat Kabupaten Bangka through the central rekapan monthly absentee?. Research aims to understand and analyzes policy implementation for fingerprints (the finger on the employee performance) in improving civil within the regional secretariat of the district bangka central, knowledge and assess the factors that which and knowledge and analyze the efforts. Descriptive qualitative use of this research aimed at certain objectively part of them supported by data obtained by means of observation, interviews and involvement with an object research to analyzed data beginning with a reduction process data, presentation of data and the withdrawal of the conclusions. As a basis for theory used the theory of implementation of public policy models Van Metter and Van Horn (Agustino, 2017:133-136) Research shows that the implementation of policy for fingerprint in improving the performance of civil servants at the secretariat of the district bangka central has been well proven at a rate the discipline was up to $85 \%$ while the civil servant performance was at in the the secretariat of the district bangka central not very well boss still lack work ethic and loyalty to superiors, and lack of motivation and zeal for work. But the effort should be made to improve the performance of the civil servant by increasing competence and training development programs, by providing reward and punishment system and character building to the civil servant.
\end{abstract}

Keywords: policy implementation, fingerprints attendance, performance.

\section{ABSTRAK}

Implementasi Kebijakan Absensi Sidik Jari (Finger Print) di Sekretariat Daerah Kabupaten Bangka Tengah secara umum telah sesuai dengan Kebijakan Pemerintah pada Peraturan Pemerintah Nomor 53 Tahun 2010 tentang Disiplin Pegawai Negeri Sipil, akan tetapi apakah dalam pelaksanaannya kebijakan absensi elektronik ini dapat meningkatkan kinerja pegawai negeri sipil di Sekretariat Daerah Kabupaten Bangka Tengah dengan melalui hasil rekapan 
absensi bulanan? Penelitian ini bertujuan untuk mengetahui dan menganalisis implementasi kebijakan absensi sidik jari (finger print) dalam meningkatkan kinerja pegawai negeri sipil di Sekretariat Daerah Kabupaten Bangka Tengah, mengetahui dan mendeskripsikan faktor penghambat dan menganalisis upaya-upaya yang dilakukan. Penelitian ini menggunakan metode deskriptif kualitatif yang bertujuan menggambarkan tentang keadaan secara objektif yang didukung dengan data yang diperoleh melalui observasi, wawancara dan keterlibatan dengan objek penelitian untuk menganalisis data yang diawali dengan proses reduksi data, penyajian data dan penarikan simpulan. Sebagai landasan teori digunakan teori implementasi kebijakan Publik Model Van Metter dan Van Horn (Agustino, 2017:133-136) Hasil penelitian menunjukkan bahwa implementasi kebijakan absensi sidik jari (finger print) di Sekretariat Daerah Kabupaten Bangka Tengah sudah baik dibuktikan dengan tingkat kedisiplinan mencapai 85\% sedangkan kinerja pegawai negeri sipil di Sekretariat Daerah Kabupaten Bangka Tengah kurang baik dibuktikan masih rendahnya etos kerja dan keloyalan kepada atasan, dan hilangnya motivasi dan semangat dalam bekerja. Namun upaya yang harus dilakukan dalam meningkatkan kinerja pegawai negeri sipil tersebut dengan cara meningkatkan kompetensi dan program pengembangan praktik dan pelatihan, dengan memberikan sistem reward dan punishment serta pembinaan karakter kepada PNS.

Kata kunci: implementasi kebijakan, absensi sidik jari (finger print), kinerja

\section{PENDAHULUAN}

$\mathrm{M}$

enurut Undang-Undang Nomor 5 Tahun 2015 tentang Aparatur Sipil Negara bahwa Pegawai Aparatur Sipil Negara yang selanjutnya disebut Pegawai ASN adalah pegawai negeri sipil dan pegawai pemerintah dengan perjanjian kerja yang diangkat oleh pejabat pembina kepegawaian dan diserahi tugas dalam suatu jabatan pemerintahan atau diserahi tugas negara lainnya dan digaji berdasarkan peraturan perundangundangan.

Dalam rangka meningkatkan citra, kerja dan kinerja instansi pemerintah menuju ke arah profesionalisme dan menunjang terciptanya pemerintahan yang baik, perlu adanya penyatuan arah dan pandangan bagi pegawai pemerintah yang dapat dipergunakan sebagai pedoman atau acuan dalam melaksanakan tugas baik managerial maupun operasional di seluruh bidang tugas dan unit organisasi instansi pemerintah secara terpadu. Untuk itu dalam meningkatkan citra, kerja dan kinerja pegawai tersebut perlunya pendisiplinan pegawai tersebut.
Berdasarkan Peraturan Pemerintah Nomor 53 Tahun 2010 tentang Disiplin PNS pada Pasal 3 yang berbunyi "PNS wajib masuk kerja dan menaati ketentuan jam kerja”. Disiplin PNS adalah kesanggupan PNS untuk menaati kewajiban dan menghindari larangan yang ditentukan dalam peraturan perundang-undangan dan/atau peraturan kedinasan yang apabila tidak ditaati atau dilanggar maka akan dijatuhi hukuman. Akan tetapi pada kenyataannya masih ada pegawai yang melakukan pelanggaran.

Dalam penelitian ini studi kasus yang akan diangkat dan diambil oleh peneliti, yaitu di Sekretariat Daerah Kabupaten Bangka Tengah. Di mana kelemahan di Sekretariat Daerah Kabupaten Bangka Tengah yang disebutkan dalam Rencana Strategis Sekretariat Daerah Kabupaten Bangka Tengah Tahun 2016-2021 salah satunya ialah masih rendahnya kualitas sumber daya manusia (SDM) dalam melaksanakan tugas, pokok dan fungsinya, dan sebagian pegawai masih beranggapan yang penting sudah absensi finger print setelah absensi keluyuran untuk sarapan pagi dan mengesampingkan tugas pokok dan fungsinya, sehingga apabila pegawai lain atau atasannya lagi membutuhkan pegawai 
tersebut maka kesulitan mencarinya dan pekerjaan di kantor akan menjadi sering tertunda. Selain itu di Sekretariat Daerah Kabupaten Bangka Tengah juga masih adanya pegawai yang tidak menaati peraturan yang sudah diatur dalam bekerja untuk melakukan absensi sidik jari finger print) seperti di waktu datang atau pagi, waktu istirahat dan waktu pulang atau sore, upacara hari Senin dan senam di hari Jumat. Hal ini terbukti karena peneliti sendiri bertugas di Sekretariat Daerah Kabupaten Bangka Tengah.

\section{Identifikasi Masalah}

1. Masih rendahnya kualitas sumber daya manusia (SDM) dalam melaksanakan tugas, pokok dan fungsinya sehingga pegawai hanya mementingkan kehadiran namun mengesampingkan tugas pokok dan fungsinya atau beranggapan yang penting absensi terpenuhi dikarenakan kurangnya tanggung jawab dari pegawai;

2. Masih belum efektifnya penerapan absensi sidik jari (finger print) 4 kali dalam 1 hari kerja bagi pegawai di Sekretariat Daerah Kabupaten Bangka Tengah dengan dibuktikan masih adanya pegawai yang hadir di atas jam mulai masuk kerja dan tidak absen siang atau istirahat serta pulang dalam jam kerja;

3. Jauhnya jarak tempuh sebagian pegawai dari tempat tinggal ke lokasi kerja;

4. Masih adanya diskriminasi atau toleransi antara pejabat dengan pegawai (staf);

5. Masih lambannya proses pencairan Tambahan Penghasilan Pegawai (TPP) dikarenakan hasil rekaman rekap absensi dari mesin absensi setiap OPD harus melalui penginputan manual yang dilakukan oleh pegawai di BKPSDMD.

\section{METODE PENELITIAN}

Metode Penelitian yang digunakan adalah metode penelitian kualitatif bersifat deksriptif-induktif dengan data yang diperlukan data primer dan data sekunder dan teknik pengumpulan data melalui teknik wawancara, dokumentasi dan observasi dengan teknik analisis data dengan reduksi data, penyajian data dan penarikan simpulan

\section{KAJIAN PUSTAKA}

Dalam penelitian ini peneliti menggunakan indikator-indikator model implementasi kebijakan publik menurut Van Metter dan Van Horn, yaitu ukuran dan tujuan kebijakan, sumber daya, Karakteristik Agen pelaksana, Sikap/kecenderungan (disposition) para pelaksana, Komunikasi antarorganisasi dan aktivitas pelaksana, Lingkungan ekonomi, sosial dan politik. (Agustino, 2017:133-136) dan juga menggunakan teori Faktor Memengaruhi Kinerja menurut Wirawan (2012:6-8), yaitu faktor internal pegawai, faktor lingkungan internal organisasi, dan faktor lingkungan eksternal organisasi.

\section{HASIL PENELITIAN DAN PEMBAHASAN}

\section{Ukuran dan Tujuan Kebijakan}

Standar keberhasilan dari implementasi kebijakan absensi sidik jari (finger print) ini ialah pegawai negeri sipil di Sekretariat Daerah harus menyadari kewajibannya dan tanggung jawabnya sebagai pegawai yang salah satunya adalah memenuhi disiplin kehadiran dengan bertujuan agar kinerja PNS ikut meningkat. Hal ini dapat dibuktikan dengan bahwa pegawai negeri sipil di Sekretariat Daerah Kabupaten Bangka Tengah dengan mengunggah data absensi melalui aplikasi Si Pelawan.

Dengan tujuan untuk meningkatkan disiplin dan kinerja pegawai negeri sipil yang mana jam kerja pegawai sebanyak 37,5 jam ini maka pegawai diharapkan untuk menyadari hal tersebut sehingga tujuan dari kebijakan absensi sidik jari ini tepat dan berjalan dengan efektif. Untuk meningkatkan 
disiplin pegawai negeri sipil maka harus diperkuat dengan ketentuan yang diatur oleh Peraturan Bupati Bangka Tengah Nomor 27 Tahun 2010 tentang Disiplin Jam Kerja Pegawai di Lingkungan Pemerintah Kabupaten Bangka Tengah

\section{Sumber Daya}

Pertama, para pegawai sangat siap dengan adanya peralihan presensi melalui aplikasi Si Pelawan, hal ini juga bisa dikatakan untuk mencegah penularan daripada virus Covid-19 yang semakin hari semakin mengkhawatirkan masyarakat dan juga para pegawai yang ada di Sekretariat Daerah. Kedua, respons atau tanggapan dari PNS sangat positif dengan adanya aplikasi Si Pelawan PNS akan lebih tepat waktu untuk melakukan absensi dan tidak merasa terburu-buru untuk datang ke kantor. Ketiga, sarana dan prasarana sudah disiapkan satu buah dan dipasang dalam ruangan khusus untuk absensi. Namun pada saat pandemi ini dengan melalui aplikasi Si Pelawan maka seluruh PNS harus mempunyai Smartphone berbasis android untuk melakukan absensi.

\section{Karakteristik Agen Pelaksana}

Pertama, peran dari pimpinan yang ada di Sekretariat Daerah dalam melakukan pengawasan implementasi kebijakan absensi sidik jari (finger print) sangat ketat, dimulai dari Kepala Bagian Umum, Asisten Administrasi Umum dan Sekretaris Daerah. Peran mereka dalam pengawasan sangat dibutuhkan dalam hal meningkatkan disiplin dan kinerja PNS yang ada di Sekretariat Daerah. Kedua, pelaksanaan absensi sidik jari (finger print) di Sekretariat Daerah sudah tidak kaku dan pegawainya mudah menyesuaikan namun dalam kesehariannya yang sebagian pegawai masih ada yang malas-malasan dan tenaga honorer juga kadang ada yang tidak masuk kerja satu hari, tetapi ini persentasenya rendah. Oleh karena itu, dapat dikatakan lebih banyak yang disiplin daripada yang tidak disiplin.
Ketiga, PNS yang apabila melanggar disiplin dengan tidak melaksanakan absensi sidik jari (finger print) tidak begitu saja pimpinan membiarkan pegawai tidak mau mematuhi peraturan yang sudah dibuat, akan tetapi para pimpinan tetap menegaskan kepada seluruh PNS untuk selalu bersikap disiplin dan bekerja secara bertanggung jawab sebagaimana menjadi kewajiban PNS pada Peraturan Pemerintah Nomor 53 Tahun 2020 tentang Disiplin PNS dan juga untuk memberikan sanksi yang diberikan pengurangan TPP hal ini sesuai dengan Peraturan Bupati Bangka Tengah Nomor 15 Tahun 2020 tentang Petunjuk Teknik Pemberian Tambahan Penghasilan bagi Pegawai ASN di Lingkungan Pemerintah Kabupaten Bangka Tengah

\section{Sikap atau Kecenderungan Para Pelaksana}

Apabila dilihat dari sikap atau kecenderungan (disposition) para pelaksana kebijakan dalam hal ini pegawai negeri sipil yang ada di Sekretariat Daerah dengan kebijakan absensi sidik jari (finger print) tersebut maka dalam kondisi pandemi virus Covid-19 ini Pemerintah Kabupaten Bangka Tengah sangat memprioritaskan para pegawai agar tetap disiplin dengan salah satu tetap melaksanakan absensi sidik jari (finger print) melalui aplikasi Si Pelawan sehingga para pegawai bisa diawasi kedisiplinannya. Dengan kebijakan ini sikap para pegawai merespons dengan baik dan mengapresiasi kebijakan dari Pemerintah Kabupaten Bangka Tengah tersebut ini dapat dilihat dengan para pegawai tetap melaksanakan absensi sidik jari (finger print) melalui aplikasi Si Pelawan.

\section{Koordinasi AntarOrganisasi dan Aktivitas Pelaksana}

apabila melihat dari komunikasi antarorganisasi dan aktivitas pelaksana di dalam implementasi kebijakan absensi sidik jari (finger print) dalam meningkatkan 
kinerja pegawai negeri sipil di Sekretariat Daerah bahwa koordinasi yang dilakukan antara pihak BKPSDMD dengan OPD lainnya mengenai peralihan mesin absensi sidik jari (finger print) ke berbasis android ini sangat intens supaya para pegawai negeri sipil mudah memahami cara penggunaan aplikasi tersebut sehingga ke depannya tidak ada kendala dan apabila ada yang belum memahami para pegawai bisa langsung menanyakan hal-hal yang belum dipahami ke Bagian Umum di Sekretariat Daerah. dan koordinasi tetap terus berjalan baik melalui sosial media maupun sosialisasi langsung ke OPD lainnya.

\section{Lingkungan Ekonomi, Sosial, dan Politik}

Kondisi kerja pada saat ini memang ada perubahan karena adanya sistem shift sehingga pegawai yang tetap berada di kantor tidak banyak namun semua pekerjaan tetap dituntut untuk harus diselesaikan baik pegawai yang bekerja dari rumah maupun di kantor. Adapun perubahan kinerja yang terjadi tetap ada namun tidak terlalu signifikan karena melalui aplikasi Si Pelawan pegawai tetap wajib melakukan absensi empat kali dalam sehari seperti biasanya dan tetap menginput pekerjaan setiap harinya melalui aplikasi Si Ketawai. Sedangkan tingkat kedisiplinan pada saat seperti ini dapat dikatakan pegawai yang ada di Sekretariat Daerah sudah menunjukkan kedisiplinannya sudah mencapai 85\%.

\section{Implementasi Kebijakan Absensi Sidik Jari (Finger Print)}

\section{a. Faktor Internal Pegawai}

Faktor internal pegawai adalah menjadi salah satu faktor penghambat dalam meningkatkan kinerja PNS, hal ini dapat dibuktikan bahwa adanya pegawai negeri sipil dan tenaga honorer (PHL) masih kurangnya kesadaran tentang pentingnya disiplin dalam bekerja terutama mengenai disiplin baik dalam absensi maupun pelaksanaan apel pagi, apel sore, upacara hari Senin, upacara bulanan dan senam pada Jumat, Kurangnya loyalitas baik pegawai negeri sipil maupun tenaga honorer (PHL) kepada atasan dikarenakan adanya kesenjangan antara pejabat eselon dengan non eselon mengenai pengurangan tunjangan (TPP), serta Hilangnya motivasi dan semangat dalam bekerja baik pegawai negeri sipil maupun tenaga honorer (PHL) dikarenakan tidak lagi menerima gaji/ upah secara utuh.

b. Faktor Lingkungan Internal Organisasi

Faktor lingkungan internal organisasi juga menjadi faktor penghambat dalam meningkatkan kinerja PNS, hal ini dapat dibuktikan bahwa Keterbatasan teknologi (mesin absensi) yang ada sehingga terjadi antrean yang panjang ketika melakukan absensi baik pada saat jam masuk kerja, istirahat maupun pulang kerja, Masih lemahnya strategi oleh pimpinan kepada para pegawai negeri sipil dan tenaga honorer (PHL) agar disiplin adalah menjadi kebutuhan dalam bekerja dan dapat menjadi budaya yang diteruskan kepada generasi-generasi selanjutnya serta Masih terpengaruhnya dengan rekan kerja dalam hal pelanggaran, seperti ketika salah satu pegawai tidak masuk dikarenakan izin atau sakit maka pegawai lainnya juga terpengaruh untuk tidak masuk kerja dengan berbagai alasan, hal ini sering terjadi pada Jumat.

c. Faktor Lingkungan Eksternal Pegawai

Faktor lingkungan eksternal organisasi juga menjadi faktor penghambat dalam meningkatkan kinerja PNS, hal ini dapat dibuktikan bahwa Masih adanya budaya baik pegawai negeri sipil dan tenaga 
honorer(PHL)yangingin meliburkan diri dari jam kerja tanpa adanya izin kepada atasan pada setiap bulannya misalnya untuk pergi liburan pada kerja, Masih rendahnya tunjangan kinerja (TPP) bagi pegawai non eselon, dan rendahnya gaji/upah bagi tenaga honorer (PHL) sehingga berdampak pada kinerja dan kehidupan sosial dari pada pegawai dan tenaga honorer tersebut, Masih adanya baik pegawai negeri sipil maupun tenaga honorer (PHL) saling berlomba (kompetitor) untuk tidak melaksanakan absensi sidik jari (finger print), apel pagi dan apel sore, upacara bulanan maupun senam. Hal ini dibuktikan pada saat pelaksanaan apel maupun upacara baik pegawai negeri sipil maupun tenaga honorer (PHL) adanya pemalsuan tanda tangan di absen manual yang di mana akan diserahkan kepada BKPSDMD.

\section{Upaya yang dilakukan dalam meningkatkan kinerja pegawai negeri sipil}

a. Meningkatkan kompetensi baik pegawai negeri sipil maupun tenaga honorer (PHL) dalam hal pengetahuan, keterampilan, perilaku dan pengalaman untuk melakukan suatu pekerjaan atau berperan secara efektif dalam memahami pentingnya kewajiban untuk disiplin.

b. Meningkatkan program pengembangan kepada pegawai negeri sipil maupun tenaga honorer (PHL) dengan cara mengikuti praktik maupun pelatihan disipliner seperti diklatpim, pembinaan disiplin bekerja sama dengan TNI maupun Polri, agar lebih memahami dan menjadikan diri lebih disiplin baik dalam bekerja maupun dalam kehidupan bermasyarakat;

c. Dengan tetap memberikan sistem rewards kepada pegawai negeri sipil yang teladan dalam bekerja maupun yang berprestasi dalam pendidikan seperti pemberian hadiah umroh ke tanah suci dan studi banding ke luar negeri. dan memberikan punishment kepada pegawai negeri sipil yang tidak patuh pada peraturan dan mendapatkan sanksi disiplin seperti pemberhentian secara hormat atau tidak hormat, menurunkan pangkat/golongan dan tidak memberikan jabatan.

d. Diundangnya penceramah/motivator untuk memberikan tausiah/motivasi kepada pegawai negeri sipil dengan tujuan terbentuknya karakter pegawai yang amanah dalam menjalankan setiap pekerjaan yang diberikan agar tidak terjadi penyimpangan seperti korupsi.

\section{SIMPULAN}

1. Berdasarkan data hasil penelitian secara keseluruhan diatas, bahwa implementasi kebijakan absensi sidik jari (finger print) dalam meningkatkan kinerja pegawai negeri sipil di Sekretariat Daerah Kabupaten Bangka Tengah sudah terlaksana dengan baik. Hal tersebut dapat dilihat dengan terpenuhinya tujuan dan standar implementasi kebijakan, pemanfaatan sumber daya yang berkualitas dan berinovasi, karakteristik pelaksana kebijakan yang mendukung, sikap pelaksana kebijakan yang merespons dengan positif, komunikasi antarorganisasi dan pelaksana kebijakan yang terkoordinasi dengan baik serta mencerminkan adanya peningkatan disiplin dalam bekerja dan suasana kerja yang lebih kondusif.

2. Namun faktor yang menjadi penghambat kinerja ialah faktor internal pegawai itu sendiri hal ini ditemukannya etos kerja dan keloyalan kepada atasan masih rendah, serta hilangnya motivasi dan semangat dalam bekerja dikarenakan 
tunjangan untuk pegawai masih rendah dan gaji untuk tenaga honorer masih rendah, yang di mana baik bagi pegawai maupun tenaga honorer tunjangan/ gaji/upah menentukan standar dan kualitas hidupnya, merupakan ukuran tenaga pikiran, waktu, risiko kerja dan kinerja yang diberikan kepada instansi atau organisasi, dan juga mencerminkan kualitas dan kebahagiaan hidupnya pada masa tua nanti.

3. Upaya yang dilakukan dalam meningkatkan kinerja pegawai negeri sipil di Sekretariat Daerah Kabupaten Bangka Tengah melalui kebijakan absensi sidik jari (finger print), yaitu dengan cara meningkatkan kompetensi dan program pengembangan praktik dan pelatihan, dengan memberikan sistem reward dan punishment, pembinaan karakter (tausiah) baik kepada PNS maupun tenaga honorer. Serta memberikan kompensasi/upah yang sesuai dengan standar UMR sehingga bisa meningkatkan motivasi dan inovasi dalam bekerja.

\section{SARAN}

1. Agar pimpinan yang ada di Kabupaten Bangka Tengah untuk tetap terus memberikan pengawasan, pembinaan dan hukuman kepada pegawai supaya pegawai tetap meningkatkan kedisiplinannya dalam bekerja sehingga akan meningkatnya kinerja yang akan dicapai agar kebijakan absensi sidik jari (finger print) yang saat ini sudah optimal maka ke depannya semakin optimal dan akan lebih baik lagi;

2. Perlunya penguatan kepada seluruh pegawai negeri sipil di Lingkungan Kantor Sekretariat Daerah Kabupaten Bangka Tengah untuk terus menjaga eksistensi lembaga tempatnya bekerja secara khusus dan Pemerintah
Kabupaten Bangka Tengah secara umum serta jati dirinya sebagai pegawai negeri sipil yang selalu menjaga sikap disiplin dan meningkatkan kinerja sesuai dengan Peraturan Pemerintah Tahun 2010 tentang Disiplin Pegawai Negeri Sipil (PNS);

3. Dengan adanya peningkatan teknologi terbaru, yaitu menggunakan absensi sidik jari (finger print) melalui Aplikasi $\mathrm{Si}$ Pelawan, sehingga ke depannya untuk meneruskan kebijakan tersebut agar pegawai negeri sipil di Kabupaten Bangka Tengah tetap meningkatkan disiplin dalam menciptakan situasi yang lebih kondusif, dapat termotivasi serta berinovasi dalam bekerja, dan juga dapat menciptakan budaya kerja yang baik dalam melaksanakan tugasnya di kantor.

\section{DAFTAR PUSTAKA}

Abidin, Said Zainal, 2012, Kebijakan Publik Edisi 2, Salemba Humanika, Jakarta.

Agustino, Leo, 2017, Dasar-Dasar Kebijakan Publik, Alfabeta, Bandung.

Amirullah, 2015, Manajemen Strategi: TeoriKonsep-Kinerja, Mitra Wacana Media, Jakarta.

Akbar Bahrullah, 2013, Sistem Pengawasan Keuangan Negara Di Indonesia, CV. Bumi Metro Jaya, Jakarta.

2013, Akuntansi Pemerintahan, CV. Bumi Metro Jaya, Jakarta.

2014, BUMN dan Kesejahteraan Rakyat, Pusat Kajian Keuangan Negara, Prenada Media, Jakarta.

Arikunto, Suharsimi, 2010, Prosedur Penelitian suatu Pendekatan Praktik, PT Rineka Cipta, Jakarta.

Barret, S., 2004, Time fore a Revival? Personel Reflictions on 20 Years of Implementation Studies, Jurnal Public Administration 82:249-262. 
Creswell, W. John, 2016, Research Design: Pendekatan Metode Kualitatif, Kuantitatif, dan Campuran Edisi Keempat (Penerjemah: Achmad Fawaid dan Rianayati Kusmini Pancasari), Pustaka Pelajar, Yogyakarta.

Dessler, Gary, 2010, Manajemen Sumber Daya Manusia, Penerjemah: Eli Tanya, Index, Jakarta.

Indrajit, Richardus Eko dkk, 2005, E-Government In Action Ragam Kasus Implementasi Sukses di Berbagai Belahan Dunia, Andi, Yogyakarta.

Mahmudi, 2010, Manajemen Kinerja Sektor Publik, Sekolah Tinggi Ilmu Manajemen YKPN.

Mangkunegara, Prabu A. A, 2017, Manajemen Sumber Daya Manusia Perusahaan, PT. Remaja Rosdakarya, Bandung.

Mulyadi, Mohammad, 2016, Metodologi Penelitian Praktis Kuantitatif \& Kualitatif. Publica Press, Jakarta.

Moleong, J. Lexy, 2012, Metodologi penelitian Kualitatif, PT Remaja Rosdakarya, Bandung.

Narbuko, Cholid dan Achmadi, Abu, 2013, Metodologi Penelitian: Memberikan Bekal Teoretis Pada Mahasiswa tentang Metodologi Penelitian Serta Diharapkan dapat Melaksanakan Penelitian dengan Langkah-Langkah yang Benar, Bumi Aksara, Jakarta.

Nasution, S., 2014, Metode Research: Penelitian Ilmiah, Edisi 1, Cetakan 14, Bumi Aksara, Jakarta.

Nazir, Moh, 2011, Metode Penelitian, Ghalia Indonesia, Bogor.

Ndraha, Taliziduhu, 2011, Kybernology (Ilmu Pemerintahan Baru) 1, Rineka Cipta, Jakarta.

Noor, Juliansyah, 2012, Metodologi Penelitian, Kencana, Jakarta.

Ulber Silalahi, 2012, Metode Penelitian Sosial, PT. Refika Aditama, Bandung.

Sedarmayanti, 2011, Manajemen Sumber Daya Manusia: Reformasi Birokrasi dan
Manajemen Pegawai Negeri Sipil, PT. Refika Aditama, Bandung.

Sinambela, Lijan Poltak, 2012, Kinerja Pegawai Teori Pengukuran dan Implikasi, Graha Ilmu, Yogyakarta.

Sugiyono, 2017, Metodologi Penelitian Kuantitatif, Kualitatif, dan $R \& D$, Alfabeta, Bandung.

Purwanto, Erwan Agus dan Dyah Ratih Sulistyastuti, 2015, Implementasi Kebijakan Publik Konsep dan Aplikasi di Indonesia, Gava Media, Yogyakarta.

Prawirosentono, 2012, Manajemen Sumber Daya Manusia, Bumi Aksara, Jakarta.

Wibowo, 2016, Manajemen Kinerja Edisi Kelima, PT. Rajagrapindo Persada, Jakarta.

Winarno, Budi, 2012, Kebijakan Publik (Teori, Proses dan Studi Kasus), CAPS, Yogyakarta.

Wirawan, 2012, Evaluasi Kinerja Sumber Daya Manusia (Teori, Aplikasi, dan Penelitian), Salemba Empat, Jakarta.

2. Penelitian Terdahulu

Hilda Nunung, 2016, Implementasi Kebijakan Absensi Sidik Jari (finger print) di Sekretariat Daerah Kabupaten Sanggau, Skripsi.

Ika Safitri, 2012, Strategi Pengembangan Sumber Daya Aparatur dalam Peningkatan Kinerja Badan Kepegawaian Daerah di Kabupaten Maluku Tengah, Tesis.

Maisaroh, 2017, Implementasi Kebijakan Absen Elektronik Sidik Jari (finger print) terhadap Disiplin dan Kinerja PNS di MIN 1 Teladan Palembang, Tesis.

\section{Peraturan Perundang-Undangan}

Undang-Undang Nomor 5 Tahun 2015 tentang Aparatur Sipil Negara

Peraturan Pemerintah Nomor 53 Tahun 2010 tentang Disiplin Pegawai Negeri Sipil

Peraturan Bupati Bangka Tengah Nomor 27 Tahun 2010 tentang perubahan kedua atas Peraturan Bupati Bangka Tengah Nomor 64 Tahun 2009 tentang Disiplin Jam Kerja Bagi Pegawai di Lingkungan Pemerintah Kabupaten Bangka Tengah 
Peraturan Bupati Bangka Nomor 7 Tahun 2017 tentang Tambahan Penghasilan Bagi Pegawai Negeri Sipil dan Calon Pegawai Negeri Sipil

Peraturan Bupati Bangka Tengah Nomor 8 Tahun 2018 tentang Tambahan Penghasilan Bagi Pegawai Negeri Sipil dan Calon Pegawai Negeri Sipil

Peraturan Bupati Bangka Tengah Nomor 6 Tahun 2019 tentang Tambahan Penghasilan Bagi Pegawai Negeri Sipil dan Calon Pegawai Negeri Sipil

Peraturan Bupati Bangka Tengah Nomor 15 Tahun 2020 tentang Tambahan Penghasilan Bagi Pegawai Negeri Sipil dan Calon Pegawai Negeri Sipil

Peraturan Bupati Bangka Tengah Nomor 80 Tahun 2019 tentang Kedudukan, Susunan Organisasi, Tugas dan Fungsi Serta Tata Kerja Sekretariat Daerah

Surat Edaran Menteri Pendayagunaan Aparatur Negara dan Reformasi Birokrasi Nomor 19 Tahun 2020 tentang penyesuaian sistem kerja aparatur sipil negara dalam upaya pencegahan Covid-19 di Lingkungan Instansi Pemerintah

Surat Edaran Nomor 800/604/BKPSDMD/2020 tentang upaya antisipasi dan pencegahan penyebaran virus Covid-19 di Lingkungan Pemerintah Kabupaten Bangka Tengah

Surat Edaran Nomor 800/686/BKPSDMD/2020 tentang pencegahan penyebaran Corona Virus Disease (Covid-19) bagi pegawai di Lingkungan Pemerintah Kabupaten Bangka Tengah

\section{Sumber Lain}

https://www.radarbangka. Co.id/berita/detail/ koba/49633/bateng-terapkan-sistemabsensi-termonitor. Html [diakses 05 Februari 2020]

www. Absensidikjari. Co.id [diakses 12 Januari 2020]

Kabupaten Bangka Tengah dalam Angka Tahun 2020

Rencana Strategis (Renstra) Sekretariat Daerah Kabupaten Bangka Tengah Tahun 20162021 